\title{
INFLUENCE OF PHYSICAL FACTORS ON VIABILITY OF MICROORGANISMS FOR PLANT PROTECTION
}

\author{
Rais Sabirov, Ayrat Valiev, Lylia Karimova, Andrey Dmitriev, Damir Khaliullin \\ Kazan State Agrarian University, Russia \\ agromehanika116@gmail.com, ayratvaliev@mail.ru, karimova-lcd@mail.ru, avd-work@mail.ru, \\ damirtag@mail.ru
}

\begin{abstract}
The development of pathogen resistance and the relatively high cost of chemical fungicides dictate the necessity to develop alternative disease control strategies. These strategies include biological methods of plant protection. However, the effectiveness of biological plant protection depends on the biological agent's activity, which strongly depends on external physical factors. The applicant of biological remedies for seed inlay is one of the environmentally safe ways to combat seed and soil infection. However, nowadays, the impact of mechanical means during seed inoculation on the survival of microorganisms remains poorly studied. A laboratory installation has been created that makes it possible to imitate the working process of applying microorganisms to plant seeds during inlay, changing the pressure in the distribution system, the types of sprayers and the temperature of the working composition of the biological product with its further study in order to determine the number of living microorganisms remaining in it after processing. According to the results of the experimental data, graphical dependences were constructed showing the impact of pressure in the sprayer system, the temperature of the biological product and the type of spraying device on the viability of microorganisms. For microorganisms of RECB-50B (based on Bacillus sp.), RECB-14B (based on Pseudomonas putida), RECB-74F (Trichoderma viride) strains, the optimal parameters of the above factors were established during mechanical application of a biological product to the treated seeds: temperature of the working compound is 20 to $25^{\circ} \mathrm{C}$, the pressure in the biopreparation delivery system is $0.4 \mathrm{MPa}$, the optimal type of spray nozzle is experimental, adapted for working with biopreparations.
\end{abstract}

Keywords: biological product, strain, microorganism, viability, etching.

\section{Introduction}

The current level of crop development is accompanied by a high pesticidal load on cultivated plants. The high cost of pesticides and their negative impact on the ecosystem as a whole are limiting factors for intensive development of crop production and are detrimental to humans. The development of pathogen resistance and the relatively high cost of chemical fungicides dictate the necessity to develop alternative disease control strategies. These strategies primarily include the biological method of plant protection. However, the effectiveness of biological plant protection depends on the activity of the biological agent, which varies in physical factors (methods of application, pressure, temperature of working compounds, etc.) [1].

The use of biological remedies in presowing seeds treatment is one of the environmentally safe ways to combat seed and soil infection. Microorganisms in the composition of biological means of protection are natural mechanisms for controlling pests in the service of humanity [2;3].

However, the effectiveness of the use of biological preparations for plant protection is determined by the activity of the biological agent in a biological product, which varies and, to a large extent, depends on the influence of various external factors. For example, in the process of spraying crops or when seed is treated with modern machines, the microorganisms that are in the composition of biological products are influenced by such physical factors as the system pressure, temperature of the working composition, as well as design features of spraying devices, that can create sudden pressure drops or other adverse effects.

Studies [4] found that, using a tank mixture of microorganisms for spraying, it is necessary to limit the pressure to $0.5 \mathrm{MPa}$. The use of higher spraying regimes affects the reduction in the number of viable bacteria. When combining microbiological preparations and chemical, for example, herbicides in a tank mix, it is necessary to ensure that the pressure is within $0.35-0.5 \mathrm{MPa}$ in order to achieve a uniform distribution of the components of the tank mix per hectare. In addition, the savings or cost overruns of plant protection products depend on the applied pressure.

At the same time, it is known that yeasts retain their viability at a pressure of $50 \mathrm{MPa}$, and individual fungi and bacteria withstand pressures up to $300 \mathrm{MPa}$ [5]. 
Despite the rapid development of biological methods of plant protection, nowadays, questions about the influence of technical means used on the survival of microorganisms are still little studied. The purpose of this study is to study the impact of physical factors arising in the process of applying microorganisms, as a part of biological plant protection products, on seeds with the help of mechanical means on their viability.

\section{Materials and methods}

As a result of earlier studies, the factors that have the greatest impact on the viability of microorganisms of biological products were identified [6-12]:

1. Temperature of the working fluid $\left(T,{ }^{\circ} \mathrm{C}\right)$;

2. Pressure on a biological product in a mechanized spraying system $(P, \mathrm{MPa})$;

3. Design features of the biological product sprayer.

To determine the level and nature of these factors' impact on the viability of microorganisms, a new laboratory setup was created (Fig. 1 and 2).

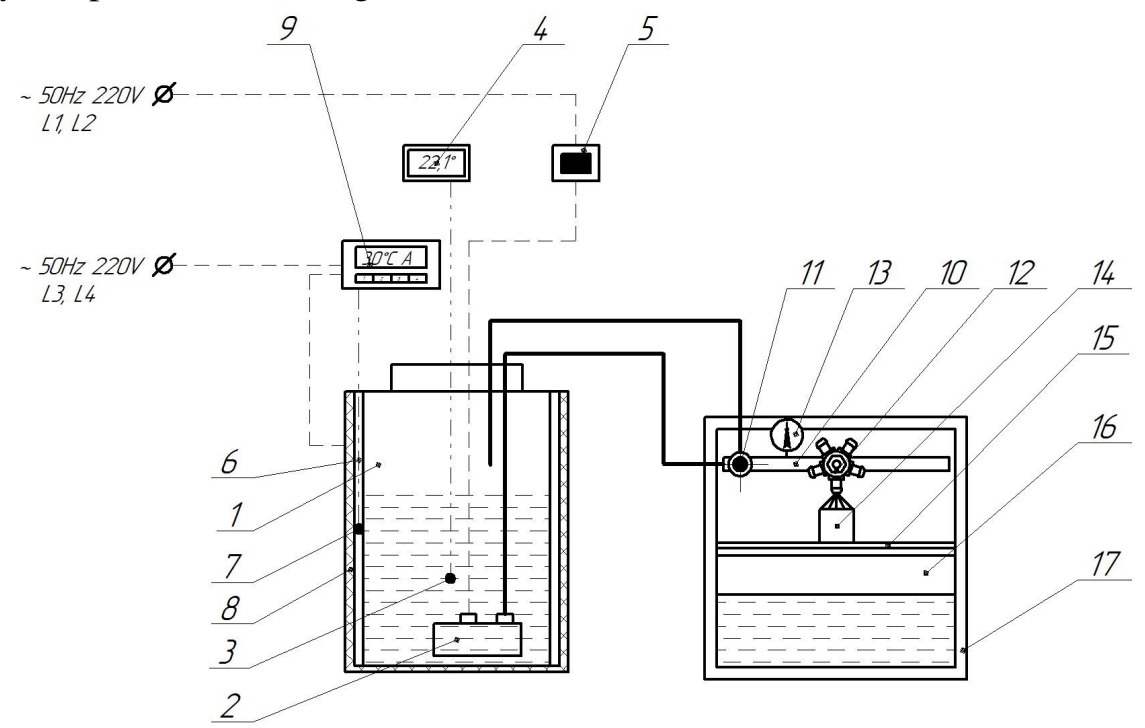

Fig. 1. Scheme of laboratory unit for testing biological products: 1 - tank of working fluid; 2 - membrane pump; 3 - fluid temperature sensor; 4 - liquid temperature gauge; 5 - pump power button; 6 - heating element; 7 - temperature sensor of the heating element; 8 -insulation;

9 - temperature regulator; 10 - pipeline; 11 - fluid pressure regulator; 12 - spray holder; 13 - manometer; 14 - weighing bottle; 15 - stand; 16 - tank for draining the liquid; 17 - frame

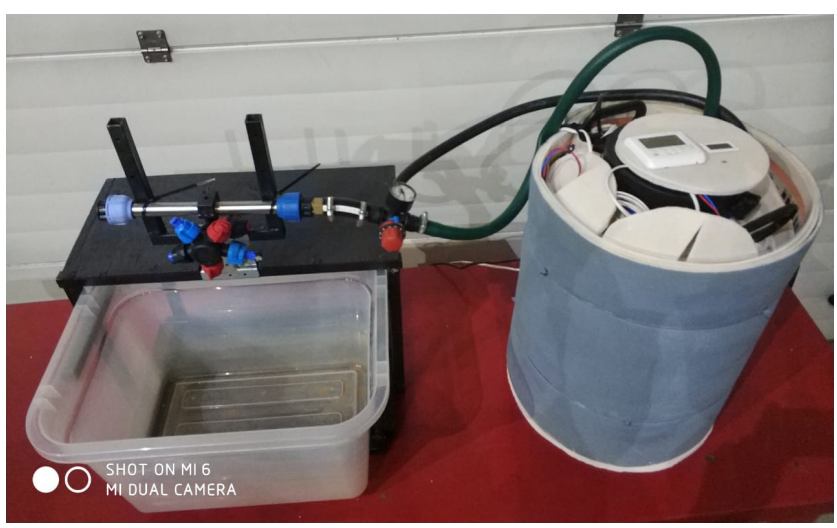

Fig. 2. General view of installation for testing biological products

The laboratory setup consists of a working fluid tank 1, in which a membrane pump 2 and a liquid temperature sensor 3 are installed, the data from which are displayed on the liquid temperature indicator 4 . The pump 2 is turned on and off by means of the key 5 . On the outer side of the working liquid tank 1 a heating element 6 is installed in layers, between which a temperature sensor 7 of the 
heating element 6 is installed. On top of the heating element 6 a heater 8 is fixed, which is also fixed across the entire surface of the tank 1 . The heating temperature of the heating element 6 is controlled by the controller 9 . The working fluid from the pump 2 is supplied to the pipeline 10 and through the fluid pressure regulator 11 is fed to the spray holder 12, which has five spray nozzles. The sprayer is quickly changed without the need to disassemble it by turning the holder along the axis. The pressure in the pipeline 10 is controlled by the pressure gauge 13. The sprayed liquid from the sprayer is supplied to the container weighing bottle 14 , installed on the stand 15 , which in turn is installed in the frame 17. Also on the frame 17 there is a tank for draining the liquid 16 and setting the pressure in the pipeline 10.

This laboratory setup allows to imitate the working process of applying a biological product to the seeds of plants during etching, changing the pressure in the distribution system, the types of sprayers, the temperature of the working composition of the biological product and its further study to determine the number of living microorganisms remaining in it after exposure to the above factors.

The laboratory setup allows changing and controlling the following parameters: working fluid temperature, $T$ (range of change $0 \ldots 90{ }^{\circ} \mathrm{C}$, measurement range $0 \ldots 90{ }^{\circ} \mathrm{C}$, step of change and control $1{ }^{\circ} \mathrm{C}$, measurement error $0.1^{\circ} \mathrm{C}$ ); pressure in the spraying system, $P$ (Range of change $0 \ldots 0,6 \mathrm{MPa}$, measurement range 0...0.6 MPa, step change and control 0.01 $\mathrm{MPa}$, measurement error $0,01 \mathrm{MPa}$ ); types of sprayers: all types of sprayers are compatible with the sprayers manufactured by ARAG S.r.l.

The created laboratory installation allows disinfection of the spraying system included in its design by heating its constituent components to the maximum viability temperature of the tested microorganisms and rinsing with specialized preparations.

The laboratory setup works as follows: the working fluid solution is poured into the tank 1 . Then, the temperature of the liquid is monitored according to the indicator 4 , which receives it from the temperature sensor of the liquid 3, if it is necessary to heat the working fluid, according to the terms of the experiments, the heating regulator 9 is turned on and the required temperature set. Heating is performed by the heating element 6 of membranous type. Liquids in the tank are protected from temperature decrease by insulation 8 . Temperature sensor 7 does not allow the heating element to overheat, giving temperature readings to the regulator 9 for the latter to take the necessary decision to continue or stop heating. The temperature of the heating element is also controlled by a visual method according to the indications of its size on the display of the regulator 9 and can be adjusted by the operator of the installation. After heating the working fluid to the required temperature, the operator must adjust the pressure at the outlet of the sprayer 12. The pressure of the working fluid is controlled by the regulator 11 and monitored by the pressure gauge 13. By placing the knob of the regulator 11 to one of the positions from 0 to 12 , the operator briefly switches on the diaphragm pump 2 by pressing the key 5 and controls the pressure in the pipeline 10 visually on the pressure gauge 13 . The sprayed liquid from the sprayer is supplied to the tank 14 installed on the stand 15.

When setting the pressure in the pipeline, the liquid from the spray holder 12 is supplied to the tank 16, installed in the frame 17. Lowering the key 5, the diaphragm pump 2 stops by disconnecting the power supply lines. Adjusting the necessary pressure, the operator conducts the necessary experiments.

Using the above-mentioned methodology of experiments, it is possible to determine the effect of the pressure $(P)$ in the sprayer system (seed treater) in the range of 0-0.6 MPa, temperature $(T)$ of the biological product in the range of $0-90{ }^{\circ} \mathrm{C}$ and the type $(N)$ of the spraying device on the viability of microorganisms in the biological product $(C F U=f(P, T, N))$.

For experimental studies to determine the influence of physical factors on the viability of microorganisms the following strains were used: RECB-50B (based on Bacillus sp.), RECB-14B (based on Pseudomonas putida), RECB-74F (Trichoderma viride). These strains were selected as the most promising, allowing to reduce the growth of seed and soil infection, as well as increase the resistance of agricultural plants to soil salinity, drought and low temperatures. Strains of bacteria of Bacillus sp. genus - producer of substances with antagonistic activity against pathogens, Pseudomonas putida - has the ability to isolate growth stimulators thereby to promote the plant growth, and Trichoderma viride - releases antibiotics, stimulates the growth and mass of the root system, which leads to an increase in the yield [13;14]. 
The viability of microorganisms was determined by laboratory sieving of the studied samples in Petri dishes under sterile conditions. For cultivation of microorganisms we used the King B. medium, which consisted of tryptone and glycerol $10 \mathrm{~g}$ per litre. To prepare the agar medium, agar was added at a concentration of $18 \mathrm{~g}$ per litre. The medium was sterilized for 40 minutes at $110^{\circ} \mathrm{C}$. After cooling the medium to $50-60^{\circ} \mathrm{C}, 10 \mathrm{ml}$ of sterile solution of magnesium sulfate 150 gram per litre and potassium phosphate disubstituted at a concentration of 150 gram per litre were added. Microorganisms were cultivated for three days in a thermostat cabinet at a temperature of $28{ }^{\circ} \mathrm{C}$, without ventilation, after which the number of colonies was counted [15].

As a biopreparation dispenser, in conducting the research, two nozzles known for the design were used - the injector and slit, and the third - an experimental dispenser of new design - a sprayer, adapted for working with biological products [16].

\section{Results and discussion}

On the basis of the above method, relevant experimental studies were carried out to determine the degree of the influence of physical factors on the viability of microorganisms. For each series of experiments, using a specific type of nebulizer and a biological product, after statistical processing, the results were presented in tabular form. For example, Table 1 shows the values of the parameters of the factors affecting the viability of microorganisms, when simulating seed treatment using an experimental sprayer adapted to work with a biological product (the experiments were performed fivefold, the table shows the average values). Similar data on the results of the experiments were obtained using injection and slit nozzles.

Table 1

Viability of microorganisms when treating seeds with biologics using an experimental sprayer, Titer $\times 10^{8} \mathrm{CFU} \cdot \mathrm{ml}^{-1}$

\begin{tabular}{|c|c|c|c|c|c|}
\hline \multirow{2}{*}{$\begin{array}{c}\text { Temperature } \\
(\boldsymbol{T}){ }^{\circ} \mathbf{C}\end{array}$} & 0.2 & 0.3 & 0.4 & 0.5 & 0.6 \\
\hline \multicolumn{7}{|c|}{ Pseudomonas putida } \\
\hline 10 & 15 & 16 & 15 & 13 & 9 \\
\hline 15 & 20 & 20 & 19 & 16 & 13 \\
\hline 20 & 34 & 33 & 29 & 27 & 20 \\
\hline 25 & 35 & 34 & 34 & 30 & 24 \\
\hline 30 & 34 & 33 & 25 & 24 & 22 \\
\hline \multicolumn{7}{|c|}{ Bacillus sp. } \\
\hline 10 & 22 & 20 & 20 & 16 & 11 \\
\hline 15 & 36 & 32 & 25 & 18 & 16 \\
\hline 20 & 48 & 45 & 40 & 36 & 34 \\
\hline 25 & 48 & 46 & 44 & 32 & 31 \\
\hline 30 & 41 & 38 & 36 & 32 & 27 \\
\hline \multicolumn{7}{|c|}{ Trichoderma viride } & & \\
\hline 10 & 16 & 15 & 13 & 13 & 12 \\
\hline 15 & 26 & 26 & 24 & 23 & 18 \\
\hline 20 & 38 & 37 & 37 & 36 & 35 \\
\hline 25 & 38 & 35 & 36 & 34 & 31 \\
\hline 30 & 39 & 37 & 36 & 32 & 29 \\
\hline
\end{tabular}

According to the results of the obtained data, graphical dependences were built showing the impact of pressure in the sprayer system, the temperature of the biological product and the type of spraying device on the viability of microorganisms after their application to the seed material by mechanical means (Fig. 3-11).

Analysing the obtained graphical dependences, it can be noted that all types of the studied strains show the best viability indicators (the number of microorganisms after processing) at a temperature of their use of $20-25^{\circ} \mathrm{C}$. Reducing the temperature of strains leads to a sharp decrease in the level of their viability and is not recommended for use. Increasing the temperature of using strains above $25^{\circ} \mathrm{C}$ is 
not advisable, since this does not lead to an increase in the level of strain viability, and in some cases, the viability decreases.

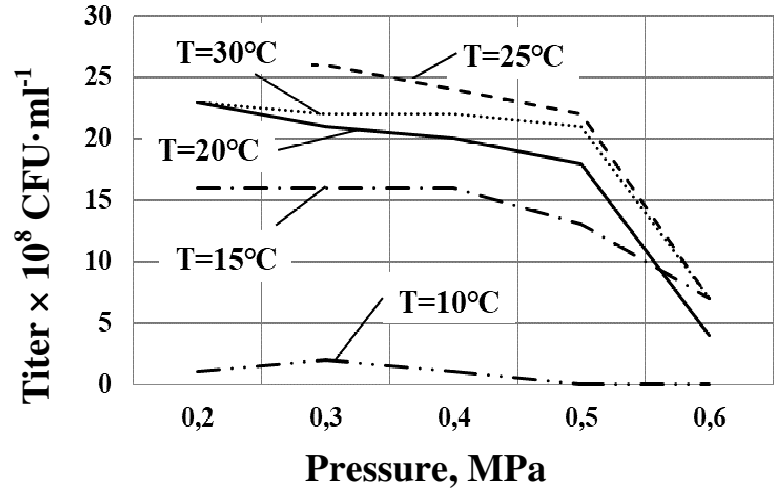

Fig. 3. Influence of pressure $(P)$ and temperature Fig. 4. Influence of pressure $(P)$ and temperature (T) on viability of Pseudomonas putida, when using injection sprayer

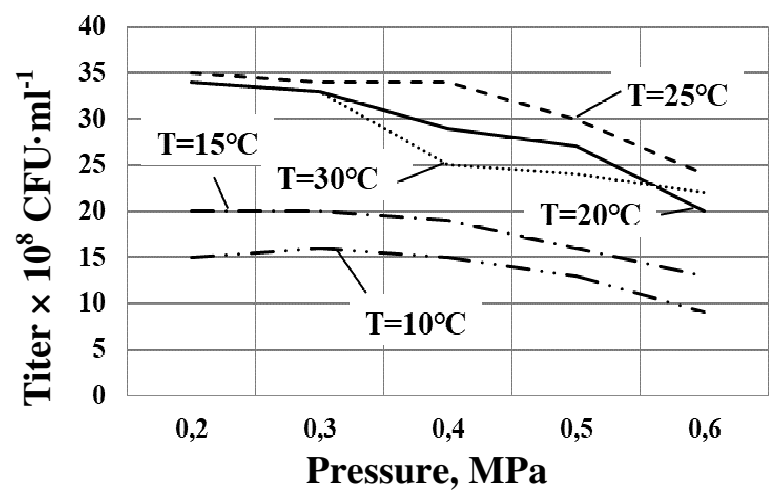

Fig. 5. Influence of pressure $(P)$ and temperature $(T)$ on viability of Pseudomonas putida, using experimental sprayer (adapted for working with biological product)

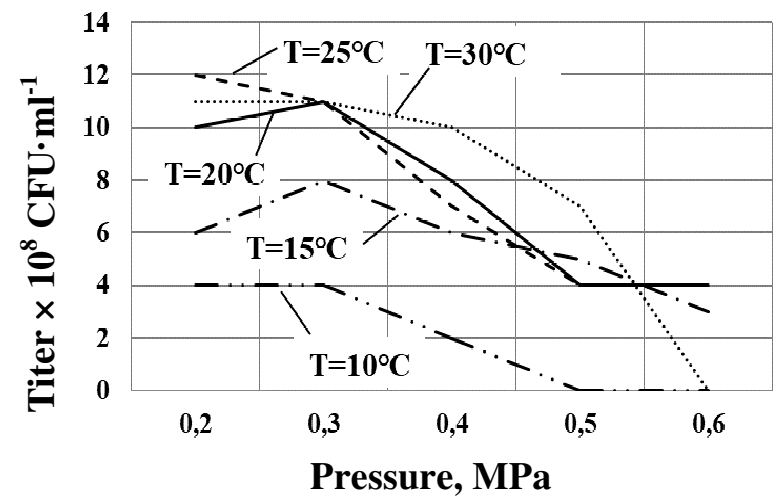

Fig. 7. Effect of pressure $(P)$ and temperature (T) on viability of Bacillus subtilis, using slotted sprayer

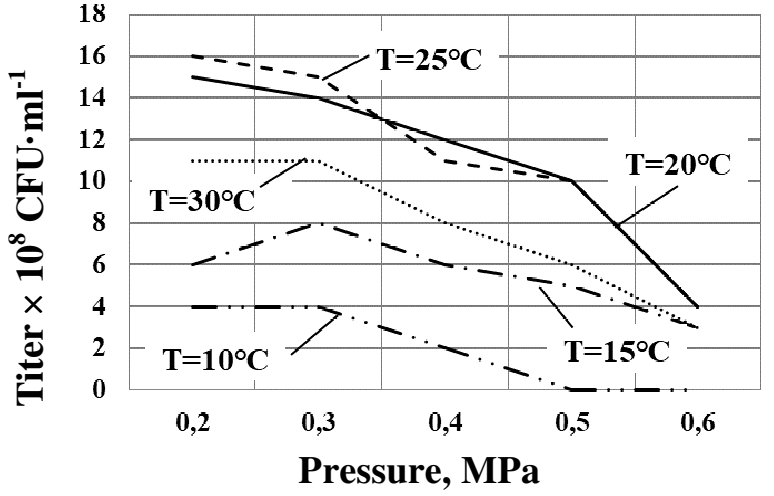

(T) on viability of Pseudomonas putida, when using slotted sprayer

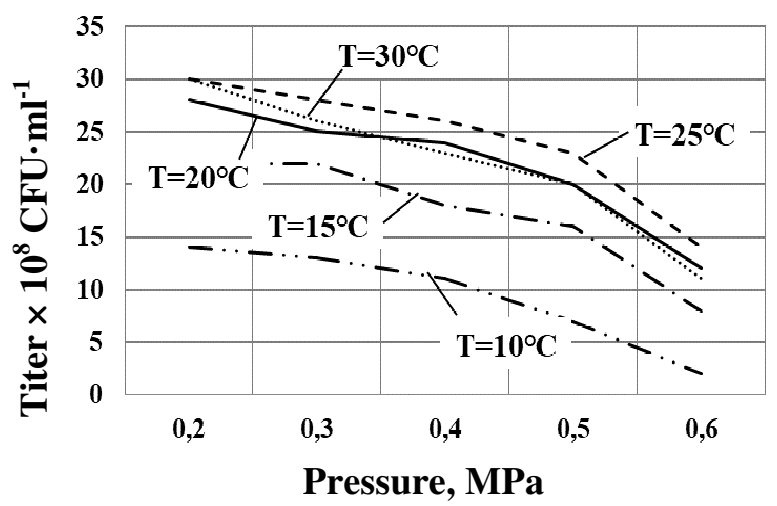

Fig. 6. Effect of pressure $(P)$ and temperature (T) on viability of Bacillus subtilis, when using injection sprayer

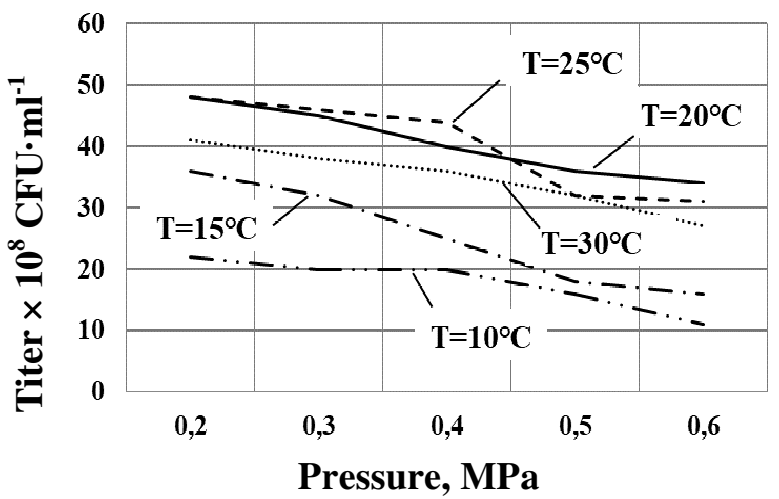

Fig. 8. Effect of pressure $(\boldsymbol{P})$ and temperature $(T)$ on viability of Bacillus subtilis, when using experimental sprayer (adapted for working with biological product) 


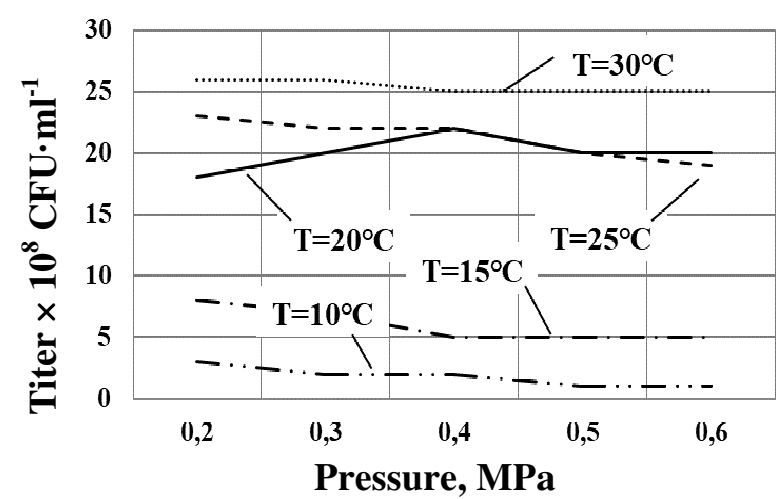

Fig. 9. Influence of pressure $(P)$ and temperature $(T)$ on viability of Trichoderma viride, when using injection sprayer

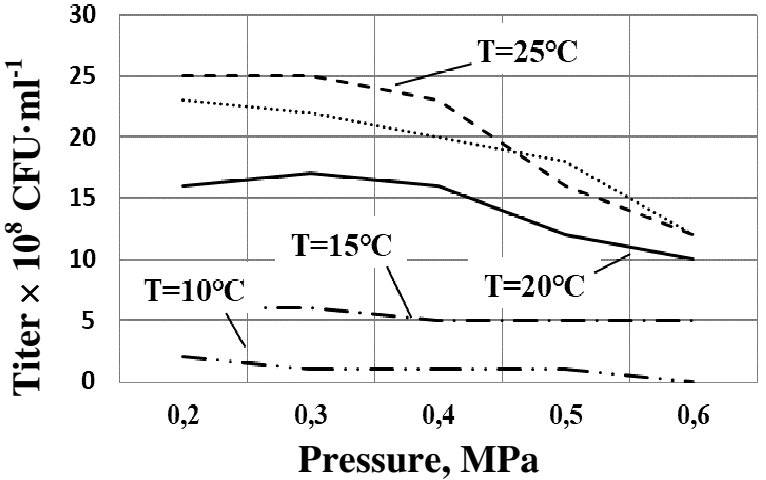

Fig. 10. Influence of pressure $(P)$ and temperature $(T)$ on viability of Trichoderma viride, using slotted sprayer

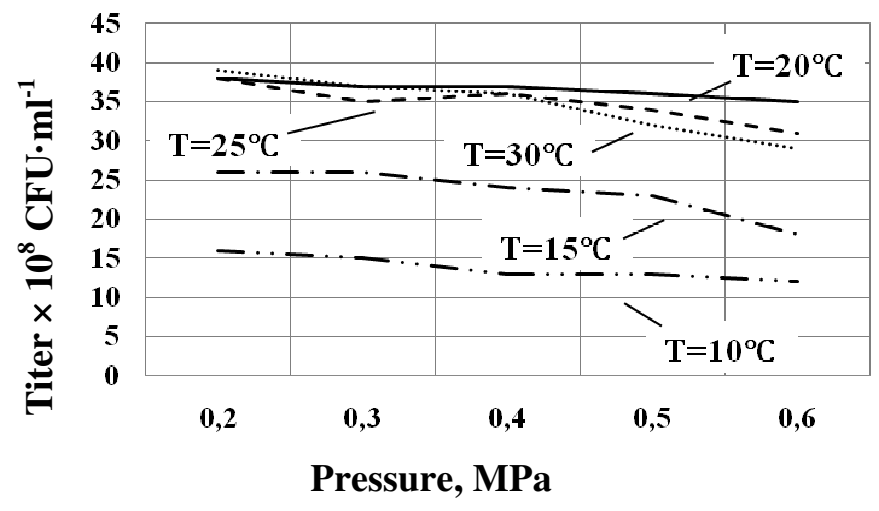

Fig. 11. Influence of pressure $(\boldsymbol{P})$ and temperature $(\boldsymbol{T})$ on viability of Trichoderma viride, using experimental sprayer (adapted for working with biological product)

The pressure in the spraying system, that is, the pressure, acting on the strains in the composition of a biological product during its mechanical application to the seeds, most strongly influences the degree of viability of microorganisms. Analysing the obtained graphical dependences, it can be seen that increasing the pressure invariably leads to a decrease in viability. It can be seen from the graphs that, when the pressure rises above $0.4 \mathrm{MPa}$, the viability of all strains starts to decrease sharply, which is not acceptable. However, at low pressure it is impossible to obtain such a dispersion of a biological product, which would allow to cover the entire surface of the seed with quality during dressing. In this case, qualitative formation of the required dispersion of a biological product, at a pressure of not higher than $0.4 \mathrm{MPa}$, can be enhanced only by using sprayers of new designs adapted for use at low pressures. Analysing the obtained graphs, it can be seen that the use of an experimental type of nebulizer gives the highest value of the viability index in the range of pressure applied to the biopreparation used in the spray system - up to 0.4 MPa.

\section{Conclusions}

1. The factors that have the greatest impact to the viability of microorganism strains in biological preparations are determined: the temperature of the working fluid, the pressure on the biological preparation in the system of mechanized spraying, and the design features of the biological preparation spray.

2. A laboratory installation was created, which allows changing and controlling the parameters of the identified factors that have the greatest impact on the viability of microorganism strains.

3. In the study of microorganism strains of RECB-50B (based on Bacillus sp.), RECB-14B (based on Pseudomonas putida), RECB-74F (Trichoderma viride) the optimal parameters of the abovementioned factors were established during mechanical application of the biological product to the 
treated seeds: working temperature composition is $20-25{ }^{\circ} \mathrm{C}$, pressure in the biopreparation delivery system - 0.4 MPa, optimal type of the spray nozzle - experimental, adapted to work with biological preparations.

\section{Acknowledgements}

This work was financed by the Ministry of Science and Higher Education of the Russian Federation. Subsidy number is 14.610.21.0017 with unique identifier of the project RFMEFI61017X0017.

\section{References}

[1] Safin R.I., Karimova L.Z., Nizamov R.M., Valiev A.R., Validov S.Z., Faizrahmanov D.I. Features of Seeds Microbiome for Spring Wheat Varieties from Different Regions of Eurasia. Proceedings of International conference "Advances in Engineering Research, International Conference on Smart Solutions for Agriculture (Agro-SMART 2018)", July 16-20, 2018, Tyumen, Russia, pp. 766-770.

[2] Calegari, F., Tassi, D., Vincini, M. Economic and environmental benefits of using a spray control system for the distribution of pesticides. Journal of Agricultural Engineering, vol. 44(2s)., 2013, pp. 163-165.

[3] WenJun Z., FuBin J., JianFeng O. Global pesticide consumption and pollution: with China as a focus. Proceedings of the International Academy of Ecology and Environmental Sciences, pp. 1(2), 2011, pp. 125-144.

[4] Котляров В.В., Сединина Н.В., Донченко Д.Ю., Котляров Д.В. Влияние давления при опрыскивании растений микробиологическими препаратами на сохранение жизнеспособности микроорганизмов и их численность. (Influence of pressure at spraying of plants by microbiological preparations on preservation of viability of microorganisms and their number). The scientific journal of the Kuban state agrarian University, vol. 115(01), 2016, pp. 1219-1232. (In Russian)

[5] Сидоренко О.Д., Борисенко Е.Г., Ванькова А.А., Войно Л.И. Микробиология: учебник для агротехнологов. (Microbiology: a textbook for agricultural technologies). Moscow: Publishing house "INFRA-M", 2005, 287 p. (In Russian).

[6] Сабиров Р.Ф., Валиев А.Р., Сёмушкин Н.И. Технические средства для обработки поверхности семян и их протравливания перед посевом средствами защиты растений. (Technical equipment for surface treatment of seeds and seed treatment before sowing by plant protection products). Collection: Agroengineering science of the XXI century scientific works of the regional scientific-practical conference, 18 January, 2018, Kazan, Russia, pp. 201-204. (In Russian)

[7] Камалетдинов P.Р. Научно-методологическое обоснование технологий и технических средств возделывания и уборки картофеля на основе объектно-ориентированного моделирования. (Scientific and methodological substantiation of technologies and technical means of potato cultivation and harvesting on the basis of object-oriented modeling). Author's abstract dis. doctor of technical Sciences: 05.20.01. Place:Bashkir. Gos. Agrar. Un-t, Ufa, Russia, 2017, 40 p. (In Russian).

[8] Сергеева, К.С., Камалетдинов Р.Р. Анализ влияния режимов хранения на различные виды микроорганизмов. (Analysis of the effect of storage modes on different types of microorganisms). Youth science and agriculture: problems and prospects: materials VII allRussian scientific and practical conference of young scientists. Part II. Bashkir state agrarian university, December 22, 2014, Ufa, Russia, pp. 75-77. (In Russian)

[9] Greg Renyer, Jim Renyer, 2016. US Patent 9,392,739 A23G 3/26, B05C 3/00, A01C 1/06 Jul.19 / 2016. Batch seed coating apparatus (In United States).

[10]Luck J.D., Zandonadi R.S., Shearer S.A., Luck B.D. Reducing pesticide over-application with map-based automatic boom section control on agricultural sprayers. Transactions - American society of agricultural engineers: general edition, vol. 3 (53), 2010, pp. 658-690.

[11] Butts, L.E., Luck, J.D., Hoffmann, W.C., Kruger, G.R. Droplet size and nozzle tip pressure from a pulse-width modulation sprayer. Biosystems Engineering. 2019. 
[12] Pergher, G., Zucchiatti, N. Influence of canopy development in the vineyard on spray deposition from a tunnel sprayer. Journal of Agricultural Engineering, vol. 49(3), 2018, pp. 164-173/

[13]Berg G., Rybakova D., Grube M., Köberl M. The plant microbiome explored: implications for experimental botany. J. Exp. Bot, vol. 67, 2018, pp. 995-1002.

[14] Haggag W. M. Role of entophytic microorganisms in biocontrol of plant diseases. Life Science Journal. vol. 7(2), 2010, pp. 57-62.

[15] King E.O., M.K. Ward, and D.E. Raney Two simple media for the demonstration of pyocyanin and fluorescin, J. Lab. Clin. Med. 44:301 307. J. Lab. Clin. Med. The Journal of laboratory and clinical medicine, vol. 44, Issue 2, 1954, pp. 301-307.

[16]Сабиров Р.Ф., Валиев А.Р., Сафин Р.И., Зиганшин Б.Г., Низамов Р.М., Дмитриев А.В., Филиппова Е.А., Каримова Л.З. Распылитель рабочего состава биопрепарата (Spray working composition of the biological product). Patent No. 2681640 RU, SPK B05B 7/1. Announced 2018113215, 11.04.2018. 11.03.2009 Byul. No. 8. (In Russian). 